\title{
Culture Behind the Wire
}

\author{
Martin Snodden, \\ Long Kesh Prison Camp
}

The cages that were Long Kesh prison camp are empty now. Only the ghosts and memories remain of the thousands of Loyalist and Republican prisoners who were incarcerated there. On June 5, 1988, the remaining 92 specialcategory prisoners were moved out of the cages and into H-Block accommodation, thus ending a unique era in the history of this troubled province.

For the 16 years of its occupation as a prison camp, the ideas of it as 'a school for subversion' or 'a university of terror' were propagated by the authorities. In contrast, Secretary of State, Merlyn Rees, once commented that 'the aimless existence followed by special category prisoners in compounds is no preparation for a return to normal living'. So just how did the men cope all those years? What did they do to avoid mental, physical, and social collapse?

From the Secretary of State, Willie Whitelaw, concession of specialcategory status to prisoners incarcerated as a result of the political turmoil in the province and their subsequent transfer behind the wire to the cages of Long Kesh in 1972, control over the men was governed by the command structures of the factionalised prisoners. The authorities' role became one of containment. Loyalist and Republican factions like the UVF (where UVF, RHC, YCV, prisoners integrated under the one banner), UDA, PIRA, OIRA, and later, the IRSP, were billeted in separate cages and the responsibity for cleanliness, maintenance, discipline, and morale were all given attention by their respective officer staff.

The level of cleanliness and maintenance varied between the factions depending on the policy adopted by them. Loyalists, on one hand, chose to make their conditions as habitable as possible, and in the process, had to haggle with the prison administrators in order to obtain the basic resources of paint (allocated once per week and saved until enough was available to cover the job in hand), disinfectant, soap, and wire wool (used to remove unwanted marks on tiled floors and for the scrubbing of ovens and cookers, brushes, mops, and even the very rubbish bins). All were a source of dispute at one time or another.

Daily work parties were organised and cleaning and maintenance duties were strictly carried out. Each man was responsible for the cleanliness in his own cubicle, a 6.5-foot high, sectioned-off area from the middle of the Nissan hut measuring 9.7 foot in floor space but restricted in volume by the curve of 
the hut. All areas were inspected by an officer during the work detail and extra duties often resulted for below standard conditions. On the other hand, Republican prisoners had a policy of not alleviating the conditions in which they found themselves incarcerated by their sworn enemies the British. They did, however, carry out basic cleaning of facilities in their cages, and each man kept himself clean. This led to great dismay amongst the prison officers and prison administrators, who often pointed an accusing finger (while still denying the Loyalists their sought-after cleaning resources!), when in embarrassment, they tried to explain to some outside visitor the contrast between Loyalist and Republican conditions.

Discipline was an ever-present factor in the daily life of the prisoner, with their officers exercising complete control over their lives, indoctrinating them with their meaning for life, while on occasion training them for death. In the 1970s, military parades were fashionable, some factions held a weekly muster parade with their volunteers turning out in uniform; however, all factions held annual parades. In the Loyalist cages, these took place in July and on Remembrance Day, while the Republicans commemorated the Easter Rising in 1916. Patriots of both traditions, from all over the six countries, (Benny from Londonderry, tragically killed while making a desperate bid for freedom; Ironjaw from Antrim; the Horse from Fermanagh; Alarm Clock from Tyrone; Ralph from Armagh;Zeb from Down), and some even from Scotland (Jock and Big Bill), England (English Bob), and Southern Ireland (Tipperary Tim), gathered for their traditional parades. Flags and uniforms were prohibited by the prison officials who searched all year round for them. Union and Ulster flags, Starry Ploughs, and Tricolours were confiscated and often found their way to the prison's black museum of memorabilia. But come a parade day, men in uniform with flags blowing in the breeze turned out in full view and in defiance of the prison authorities, taking solace and pride in their comradeship as an oration was read by some charismatic authoritarian leader of either a green or orange hue.

Since the Secretaries of State's, Merlyn Rees (1976) and Humphrey Atkinns (1980), rulings to deny to political prisoners special-category status, the numbers incarcerated in the cages decreased as the 1970s ended. The 1980s began with conflict within the cages on the acceptability of case reviews for life sentenced prisoners. This development marked the dawn of a new era for the men in the cages.

Regimental lifestyles that had existed were replaced with a commune-type existence where issues were openly discussed and a consensus of opinion sought and acted upon. Interaction between the factions, most notably between the UVF and the OIRA, increased and tribal feuds were submerged in political views which were amongst the most moderate and radical in the country.

With Nationalists publicly espousing their credited phrase 'ourselves alone,' and Loyalists knowing the reality of its meaning, having been betrayed by their 
political leaders and finding themselves in the most unpleasant situation of being imprisoned by their fellow countrymen for fighting for their people. How much more remarkable it is then that their general morale remained buoyant in the face of adversity.

Throughout the 1980s, they occupied themselves not by plotting and planning anyone's downfall, even though they endured unimaginable pettiness and psychological stress from members of the prison regime who tried to intimidate them into submission, but by continuing to cultivate their minds. Academic education, handicrafts, sport, and health and fitness featured heavily in their lives.

Many partook in education. Meetings between a cage education representative and the prison education department administrator took place once a week, and over a cup of coffee, education requests forwarded by the cage rep were discussed and provisions and resources made available to enable a prisoner's chosen passage to be as obstacle free as possible.

Most of the prisoners had no recognised academic qualifications at the time of their arrest. So over the years, full and part-time teachers were employed to go into the cages and teach eager students subjects found in any school curriculum. Irish language was surprisingly requested and taught to fainne level in a UVF cage. Some chose not to sit examinations, but a significant number did bring many achievements at ' $O$ ' and ' $A$ ' levels.

The Open University (OU), having first come into the camp in the mid 1970s for a few student prisoners, found a demand for their courses increasing in the 1980s as students climbed the academic ladder. They provided distance learning course material in prisoners' fields of personal interest such as mathematics, sociology, computing, technology, psychology, social sciences, philosophy, and history. Also tutors were sent in from the province's universities to discuss course units and prepare students for their three-hour examination.

After many hours of solitary study, a number of students gained the required credits to entitle them to a degree from the OU (seven UVF prisoners graduated while in cage 21), others followed up their studies on release by going into fulltime education at universities at home, in Britain, and in the Republic. Some, after having achieved their first degree, carried on to Honours degrees and even to postgraduate studies in the cages.

The prisoners often joked about being a captive audience but what could not be laughed at was the dedication shown to attain a pass rate many of today's Further Education colleges would be proud of. The wire may have restricted the movement of their bodies, but their minds knew no bounds in their hunger for knowledge.

Handicrafts such as leather craft, glass picture painting, soft-toy making, oil painting, and wood craft all require quite different skills. Yet these were all mastered by individuals throughout the camp without outside tuition and 
instruction, but largely by adopting a heuristic approach. Billfolds, purses, handbags, schoolboys, and leather plaques with specialised designs modelled on them were all produced by leather-working prisoners. Glass picture painting of traditional emblems and football team badges were done and framed. Micky Mouse and Kermit the Frog were two favourites for the softtoy makers. Magazine photographs of old masters' paintings were expertly copied on canvas. Irish harps and gypsy caravans, churches and windmills were competently crafted from wood. All these were done within the resource constraints set by prison officials.

Choice of sport as a pastime varied in the cages, but the most popular forms were football (Loyalists played soccer, the Republicans Gaelic), snooker, darts, and it was not unknown during the summer months to see games of tennis, volleyball, and even an occasional game of cricket being played. Injuries from broken legs to fractured cheek bones bear witness to the competitive nature with which they were played.

Health and fitness consciousness came via TV, books, magazines, and a rare instructed course from some of NI's top coaches, fuelling an already eager audience to pursue their chosen leisure activities of weight training, body building, boxing, and running (short, middle, and long distances) to a high standard. Hutchie, in his deceptive shuffling running style eating up the marathon miles as he followed the wire-cage perimeter around and around and around (seven laps to the mile) in his daily training runs, had to be seen to be believed.

But life in the cages was not always so serious. In fact, there were many lighthearted and humorous moments provided by some of the wittiest of characters one could ever hope to meet. Like the Belfast wit when a prison officer taking details of the prisoner asked him 'What do you call your, father?' and he, quick as a flash, responded with 'Daddy.' Or the time when a certain Shankill Road man suggested to a Tigers Bay man that a wet lettuce rubbed over his body would ease his discomfort from sunburn, and then set about doing it to him to the amusement of the whole cage for weeks after. And when their brand of humour was inspired by the 'rocket fuel' (poteen, made, bottled, and drunk by the men), it was a night to remember and a morning-after to forget!

And who could forget the variety of pets kept by the men: budgies, canaries, parrots, cockateels, pigeons, tropical fish, and cats. All these creatures found a home and a caring keeper, not always with the approval of the prison regime.

Another caring group were the born-again Christians. These were people, who had travelled their own road to Damascus, and like Paul they were aware of the manufactured religious beliefs that existed in society, they too had to defend their spiritual faith which differed so much from established denominations. They studied religion and formed a lasting friendship with one of their Christian brothers from Belfast Bible College, and had many Bible classes and 
services behind the wire attended and enjoyed by ministers of different denominations.

As the numbers went down, with the inevitable releases, all the activities previously described were carried on as best as possible. They were what made the culture that each man in his own way had contributed to, with which to be identified.

This 'Culture' is still alive and well. The remaining prisoners are a strong, cohesive unit. They needed the group strength to survive. There were times when it was hard for each man to keep going, but with emotional and material support from their families and friends on the outside and always someone to lend an ear to a troubled soul on the inside they managed. The men who have been freed admit the experience changed them as individuals and human beings. Like survivors of other battles, they do not talk much about themselves. Those who are left behind are now anxious to feel the fresh wind of freedom on their faces. In the meantime, they look through the wire to a 20 -foot-high concrete wall, behind which are the empty cages, and listen to the echoes on the wind.

Abbreviations:

UVF - Ulster Volunteer Force

RHC - Red Hand Commandos

YCV - Young Citizen Volunteers

UDA - Ulster Defence Association

PIRA - Provisional Irish Republican Army

OIRA - Official Irish Republican Army

IRSP - Irish Republican Socialist Party 